Study on mechanical behavior of steel fiber reinforced used fibrous materials

$$
\begin{array}{lllll}
\text { 学 } & \text { 孫 立超 (阪大) } & \text { 学 } & \text { 藤田 } & \text { 雄三(阪大) } \\
\text { 正 } & \text { 倉敷 哲生 (阪大) } & \text { 正 } & \text { 座古 } & \text { 勝(阪大) }
\end{array}
$$

Lichao SUN, Osaka University, Osaka University, 2-1 Yamadaoka, Suita, Osaka 565-0871 Japan Yuzo FUJITA, Tetsusei KURASHIKI, Masaru ZAKO.

\section{1. 緒言}

日本での繊維廃車物は年間約 200 万トンであるが, リサイ クル率は僅か $8 \%$ 程度であり, 有効な活用が課題となってい

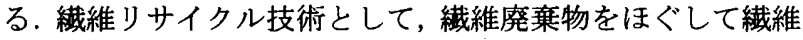
状に戻しフェルトを作成し，熱可塑性絒維をバインダーとし て混用し加熱圧縮することで製造する䋐維板としての利用 が考えられる。この故䋞維複合材料の更なる剛性や強度とい った力学的特性の向上を目的に、本研究では, 経済性の面か ら強化材としてスチールファイバーを適用し,その強化形態 を評価したので，その結果について記述する。

\section{2. スチールファイバーの強化形態の検討}

熱可塑性繊維（ポリプロピレン）を含有した故繊維のフェ ルトの層間にスチールファイバーを挿入し, 力学的特性の向 上を試みる. 成形のし易さから，強化材はスチールファイバ 一製のネット形状のものとした.このネットの挿入形態とし て 3 種類を用意した. 7 層のフェルトの最外層の下にネット を 2 層挿入する形態(Fig.1(a)), Fig.1(a)とは反対向きネットを 挿入する形態 Fig.1(b)，ネット間にフェルトを挿入する形態 (Fig.1(c))である.

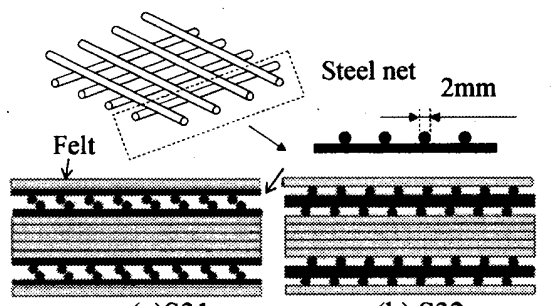

(a)S31 (b) $\mathrm{S} 32$

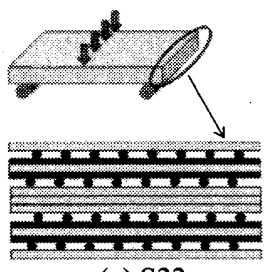

(c) S33
Fig. 1. Cross section of test specimen

JIS K 7171 に従い三点曲げ試験を行った. 試験片はスパン 間距離. $176 \mathrm{~mm}$, 厚さ $12 \mathrm{~mm}$, 幅 $50 \mathrm{~mm}$ の平板形状である. 得られた曲げ弾性率・強度の結果を Table1 に示寸. S33 の構 造が最も高い曲げ弾性率・強度を示していることがわかる. また, 試験片の変形状態に着目すると, S31, S32 と比較し て S33 では圧子近傍での変形が小さいことを確認できた.ま た, S31，S32 では層間剥離が見られたが，S33 では剥離は 生じなかった.これらの結果より，ネットとその上下のフェ ルト層の境界で, 高いアンカー効果が得られていると考える.

Table 1 Three-point bending test results

\begin{tabular}{|c|c|c|c|c|}
\hline \multirow{2}{*}{ Type specimens } & \multicolumn{3}{|c|}{ With steel fiber } & Without steel \\
\cline { 2 - 4 } & $\mathrm{S} 31$ & $\mathrm{~S} 32$ & $\mathrm{~S} 33$ & fiber \\
\hline Flexural modulus [GPa] & 2.90 & 2.23 & 3.12 & 1.24 \\
\hline Flexural strength [MPa] & 25.3 & 21.6 & 26.7 & 20.7 \\
\hline
\end{tabular}

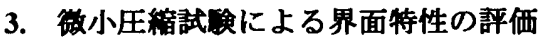

島津製作所製 MCT-W500-J を用いて微小圧縮試験を実施 し，スチールファイバー1 本周辺の界面特性を評価する：得 られた縮約弾性係数を Fig.2 に示す. A, B は異なる位置の スチールファイバーを示しており, スチールファイバー端部 からの距離に応じて結果を整理している. S33 の縮約弾性係 数が高いため, スチールネットの間にフェルト層を挿入する

ことにより, フェルト-スチールの界面特性が向上すると考 える.

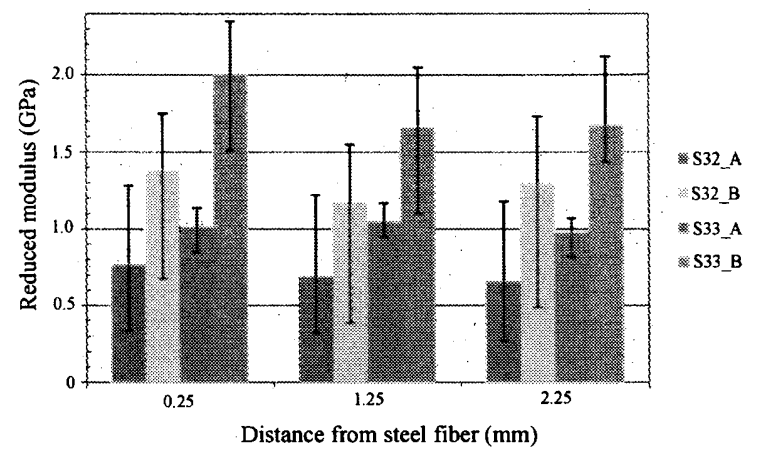

Fig. 2. Test results

\title{
4. 日本農林規格に基つく曲げたわみの評価
}

フローリング材の日本農林規格に基づき, 曲げたわみを評 価する. 上述の試験結果より, Fig.3 の強化形態 A とし, 更 に内層にあるスチールファイバーの向きを変えた強化形態 B も用意する. スキン部に強化形態 A, B を用い, コア部に はフェルト層を多層積層とし, この積層数を 3 種類に変えて, サンドイッチ構造とし，厚肉化を図る.

スパン間距離 $700 \mathrm{~mm}$ の試験片を作成し，試験片幅 $100 \mathrm{~mm}$ あたり $3 \mathrm{~kg}$ 負荷時と $7 \mathrm{~kg}$ 負荷時の曲げたわみの差を測定した. 試験片のコア部の厚みを変えて三点曲げ試験を行った結果 を Fig.4に示す，厚さが $20 \mathrm{~mm}$ あれば，強化形態 A，B はた わみ差が 3.5mm 以下である規格を満たしている.

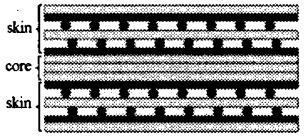

(a) Type $\mathrm{A}$

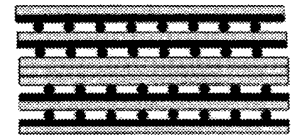

(b) Type B

Fig. 3. Cross section of test specimen

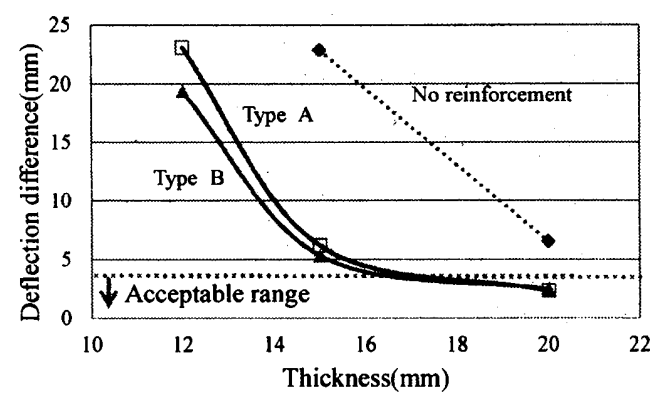

Fig. 4. Three-point bending test results

\section{5. 結言}

故綫維を用いた複合材料の剛性を強化する方法として, ス チールネットを層間に挿入したサンドイッチ構造を提案し, 適切なスチールネットの強化形態について検討した. 更に, コア部の厚みを制御することでフローリング材の日本農林 規格も許容することを示した。 